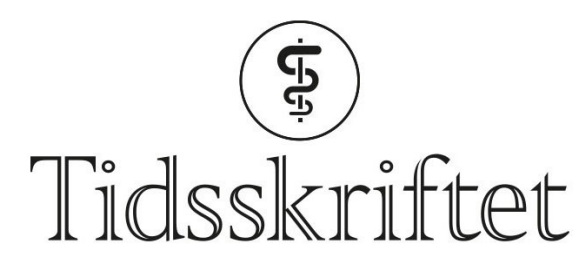

DEN NORSKE LEGEFORENING

\title{
Naturen som terapeut eller medhjelper?
}

ANMELDELSER

HARRIET HAUKELAND

Fastlege, Tanum legekontor

Slependen

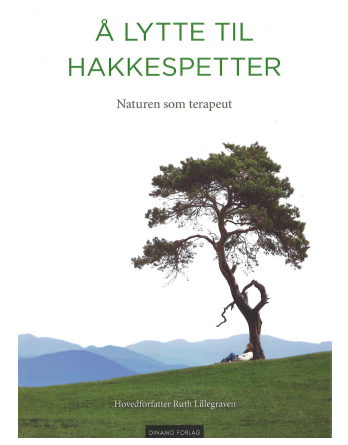

Ruth Lillegraven

Å lytte til hakkespetter

Naturen som terapeut. 191 s, ill. Snarøya: Dinamo Forlag, 2016. Pris NOK 349

ISBN 978-82-8071-318-6

Jeg har et spesielt forhold til hakkespetter! I fjor vår bestemte en hakkespett seg for å hakke et rede i den store bjerken utenfor soveværelset vårt. Kjæresten kom og de fikk mange unger. De startet livlig kl o4 hver morgen. Til glede og irritasjon for to som gjerne ville sove lenger. Vi fikk kjenne på alle følelser med naturen. Beundring over det vakre de skapte, gleden ved at de valgte akkurat vårt tre - og stor irritasjon over tretthet. Jeg var derfor svært glad for å få anmelde akkurat denne boken.

Å lytte til hakkespetter består av seks pasienthistorer og seks innlegg fra fagpersoner. Noen av innleggene har form av samtaler med forfatteren Ruth Lillegraven eller bidragsyter Simen Tveitereid, noen er på nynorsk og resten på bokmål. Alle beskriver sine erfaringer med naturen som hjelp og glede når sinnet har det vanskelig. Boken er et produkt fra Modum Bad hvor naturen har en stor del i pasientbehandlingen, og både pasientene og fagpersonene har eller har hatt tilknytning til Modum Bad. Pasienthistorienes verdi varierer, men det kommer nok mye an på om leseren er en fagperson eller ikke. Fagpersonenes innlegg er gode, tankevekkende og velskrevet. Jeg sitter igjen med en god følelse av naturens evne til å hjelpe, men også med en følelse av at dette er til tider 
unyansert, litt vel uten motforestillinger. Det finnes jo mennesker som føler seg utrygge i store furuskoger og på store stille vann.

Målgruppen hadde jeg derfor problemer med å definere. Deprimerte og psykisk syke orker sjelden å lese en bok, men mennesker på søken etter hjelp kan nok ha god nytte av denne. Jeg tror leger og også andre pasienter på vei til å bli utbrent vil ha glede av historien til den utbrente overlegen og Gry Stålseths innlegg om leger. Det er også innlegg som passer leger som skal gå over i pensjonisttilværelsen.

Boken er pent innbundet, kapitlene er inndelt med vakre bilder og dikt av forfatteren. Med godt papir og god skrift er den lettlest.

Dette er ikke en kokebok med oppskrift på hvordan man kan bruke naturen som terapeut, men en stor inspirasjon for de fleste til å bruke naturen både til glede og til hjelp.

Publisert: 13. november 2017. Tidsskr Nor Legeforen. DOI: 10.4045/tidsskr.17.0709

(C) Tidsskrift for Den norske legeforening 2020. Lastet ned fra tidsskriftet.no 